\title{
The Evaluation of Dissolved Oxygen Removal Efficiency for Membrane Degassing Process in Ultrapure Water
}

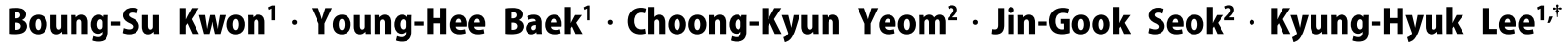 \\ ${ }^{1}$ K-water Research Institute \\ ${ }^{2}$ SepraTek
}

(Received September 26, 2019; Revised October 8, 2019; Accepted October 9, 2019)

Objectives: In this study, the efficiency of dissolved oxygen removal was evaluated in the domestic membrane degassing (MDG) process for ultrapure water production. 3M (Liqui-cel ${ }^{\mathrm{TM}}$ ) is mainly used for membrane degassing (MDG) process in ultrapure water. The domestic MDG process is used in $\mathrm{CO}_{2}$ gas processes in petrochemical processes. The water quality of $3 \mathrm{M}$ (Liqui-cel ${ }^{\mathrm{TM}}$ ) process managed below $1 \mu \mathrm{g} / \mathrm{L}$. The efficiency of dissolved oxygen removal for the domestic MDG process was evaluated and compared with that of external films.

Methods : $3 \mathrm{M}$ (Liqui-cel ${ }^{\mathrm{TM}}$ ) and domestic membrane degassing process were evaluated by ultrapure membrane degassing process. First, the DO removal rate was evaluated for the evaluation of the hollow fiber membranes, but the operating conditions such as vacuum degree and nitrogen gas injection amount were changed. Secondly, the solubility of organics in the module was evaluate. And the efficiency of dissolved oxygen removal according to four operating criteria (inlet DO concentration, vacuum level, nitrogen gas volume, and supply pressure) was evaluated.

Results and Discussion: First, the hollow fiber membrane of $3 \mathrm{M}$ (Liqui-cel $^{\mathrm{TM}}$ ) is DO $3.8 \sim 4.9 \mathrm{mg} / \mathrm{L}$ and the domestic hollow fiber membrane is $3.4 \sim 4.8 \mathrm{mg} / \mathrm{L}$ depending on the operating conditions. As a result of evaluation of the hollow fiber membrane, the removal efficiency of the domestic hollow fiber membrane was better. Secondly, As a result of the application of domestic MDG, the dissolved oxygen (DO) concentration of the product is $0 \mu \mathrm{g} / \mathrm{L}$ when the incoming DO concentration is $10 \mu \mathrm{g} / \mathrm{L}$ or less. There was no difference compared to $3 \mathrm{M}$. When the operating conditions such as incoming DO concentration, vacuum level, nitrogen gas and supply pressure were changed, the DO removal rate was lowered to $61 \sim 65 \%$.

Conclusions: In the evaluation of the MDG hollow fiber membrane, the removal efficiency of the domestic membrane was better. However, evaluating the module lowers the efficiency. The packing efficiency of the module is low and the resistance of the membrane is increased, resulting in low removal efficiency. Improvement of domestic MDG membrane should reduce the pore size of membrane and reduce the thickness of membrane. As a result, the dissolved oxygen removal efficiency of domestic MDG membrane can be improved.

Key Words: Ultrapure Water, Membrane Contactor, Membrane Degassing, Vacuum Pressure, Nitrogen Gas 


\title{
연구논문
}

\section{초순수용 막탈기공정 용존산소 제거효율 평가}

\author{
권병수 ${ }^{1} \cdot$ 백영희 ${ }^{1} \cdot$ 염충균 $^{2} \cdot$ 석진국 $^{2} \cdot$ 이경혁 $^{1+}$ \\ 'K-water연구원 \\ ${ }^{2}$ 세프라텍
}

목적: 본 연구에서는 외산탈기막이 독점적으로 사용되는 초순수 공정에서 국산 Membrane degassing (MDG)공 정을 개발하여 평가하였다. 초순수용 $\mathrm{MDG}$ 공정에 주로 사용되는 제품은 $3 \mathrm{M}$ 의 Liqui-cel ${ }^{\mathrm{TM}}$ 제품이며, 국산 $\mathrm{MDG}$ 막은 화학공정 중 $\mathrm{CO}_{2}$ 가스 공정에 사용되는 중공사막을 개선하여 모듈을 개발하였다. 초순수 공정의 최 종 용존산소 관리 수준은 $1 \mu \mathrm{g} / \mathrm{L}$ 이하이며, 국산막에 대한 용존산소 제거효율을 평가하여 외산막과 성능을 비교 평가하였다.

방법: 국산 MDG공정 개발에 대한 평가 방법으로 중공사막과 모듈에 대한 평가를 나누어 실시하였다. 우선, 중공 사막의 평가를 위해 진공도, 질소가스 주입량 등의 운전조건을 변경하여 DO 제거율을 평가하였다. 외산 및 국산 $\mathrm{MDG}$ 막을 이용하여 질소농도와 진공도를 각각 $2.5 \sim 5 \mathrm{~L} / \mathrm{min}$ 및 $30 \sim 150 \mathrm{mmHg}$ 로 변화시키며 평가하였다. 두 번 째로 모듈에 대한 평가는 유기물 용출도를 평가하였으며, 또한 인입농도, 진공도, 질소가스량, 공급압력 등 4가지 운전인자에 따른 용존산소 제거효율에 대해 평가하였다.

결과 및 토의: 첫 번째로 국내 $\mathrm{MDG}$ 중공사막의 평가결과 진공도와 질소가스량의 조건에 따라 Liqui-cel ${ }^{\mathrm{TM}}$ 막의 경우 용존산소가 $3.8 \sim 4.9 \mathrm{mg} / \mathrm{L}$ 이며, 국내 중공사막의 경우 $3.4 \sim 4.8 \mathrm{mg} / \mathrm{L}$ 이다. 중공사막의 평가결과 국내 중공사 막의 제거효율이 더 좋았다. 이는 막의 기공과 균일도에 의해 효율차이가 발생한 것이다. 두 번째로 국산 $\mathrm{MDG}$ 모듈 적용 결과 인입 DO 농도가 $10 \mu \mathrm{g} / \mathrm{L}$ 이하일 경우 생산수 $\mathrm{DO}$ 가 $0 \mu \mathrm{g} / \mathrm{L}$ 수준으로 $3 \mathrm{M}$ 막과 비교하여 차이가 없었으나, 인입 $\mathrm{DO}$ 농도, 진공도, 질소가스, 공급압력을 변경한 결과 $\mathrm{DO}$ 제거율이 $61 \sim 65 \%$ 수준으로 낮아졌다. 막의 패킹효율, 막의 두께, 기공의 사이즈에 의해 효율차이가 발생한 것이다.

결론 : MDG 중공사막에 대한 평가에서는 국산막의 제거효율이 더 좋았으며, 모듈을 구성하여 평가하면 효율이 낮 아짐을 알 수 있었으며, 이는 모듈 구성이 집약도와 막의 저항이 증가함으로 제거효율이 낮아진다. 이를 극복하기 위해서는 막의 기공 크기를 감소시키고, 막의 두께를 감소시켜 용존산소 제거효율을 높여야 한다.

주제어 : 초순수, 막접촉기, 막탈기, 진공압력, 질소가스량

\section{1. 서론}

산업용수 생산과정은 물속의 유기물, 무기물을 전처리공 정(혼화, 응집, 침전, 여과공정)에서 제거하고, 이온과 가스 등을 추가로 제거하는 후처리 공정으로 구성되어, 최종적으 로 생산된 순수 및 초순수는 석유화학, 철강, 전자, 반도체, 전기분야 등에 세정수 등으로 다양하게 사용된다. ${ }^{1,2)}$ 전 세 계 산업용수의 시장규모는 ' 17 년 약 163 조원이며, '22년 202 조원 규모로 예상되어 $24.4 \%$ 성장이 전망된다. 산업용 수 분야별 '17 '22 자본투자 연평균 성장율은 오일· 가스가 연평균 성장률 $12.3 \%$, 광업 $7.1 \%$, 전자 $7.0 \%$ 로 예상된다. 또한, 국내 산업용수 시장규모는 약 2.2조원 규모(전체 물시
장의 $14 \%$ )이며, ' 20 년 2.6 조원(자본투자 0.9 조원, 운영투자 1.7 조원)로 $19.5 \%$ 성장 전망된다. ${ }^{3)}$ 산업용수의 성장과 더불 어 초순수 공정에서 용존산소를 제거하기 위한 막접촉기 (Membrane Contactor (MC))의 적용도 확대되고 있다.

막접촉기 기술은 분리막을 통하여 흡수제와 기체를 접촉 시켜 물에 용해되어있는 하나 이상의 기체 성분을 선택적 으로 분리하는 공정이며, 액체 흡수(높은 선택도)와 막 분 리(모듈성 및 소형화)의 장점을 결합한 하이브리드 기술이 다. ${ }^{4)}$ 막접촉기는 1960 년도 Schaffer에 의해 식품, 의약 등의 수처리용으로 개념이 도입되었으며), 1980년대 Qi와 Cussler 에 의해 $\mathrm{CO}_{2}$ 분리를 위해 활용된 이후로 기체 분리 분야에 서 활발한 연구가 수행되고 있다. ${ }^{6}$ 현재 막접촉기는 액액 
추출"), 기체 흡수 및 탈거 ${ }^{8}$, 고밀도 가스 추출, 반도체 공정"), 삼투 증류법 ${ }^{10)}$ 등 다양한 응용 분야에 적용되어 개발되고 있다. 예를 들어, 보일러의 수명을 늘리기 위하여 용수에서 $\mathrm{CO}_{2}$ 를 탈기하는 시스템, 반도체 산업에서 초순수 제조 등 에 상용화된 막접촉기 공정이 가동되고 있다. 최근에는 천 연가스 정제 산업 공정, 화석연료의 연소 과정에서 발생하는 $\mathrm{CO}_{2}, \mathrm{H}_{2} \mathrm{~S}, \mathrm{SO}_{2}$ 등의 산성 가스를 저감하기 위한 막접촉기 기술 개발이 주목받고 있다.

막접촉기에서는 기존 흡수공정에 비해서 물질 전달 과정 에 분리막 저항이 추가로 존재한다. 따라서 막 두께를 감소 시키거나 표면 기공도를 증가시킴으로써 물질전달 저항을 최소화해야 할 필요가 있다. $\left.{ }^{11}\right)$ 특히, 분리막의 기공이 흡수 제에 의해 젖을 경우에는 막저항이 급격하게 증가하므로, 이를 방지하기 위하여 분리막은 높은 소수성을 가져야 한 다. 또한, 분리막은 기본적으로 고온에서 열화에 대한 우수 한 내열성, 흡수제에 대한 우수한 화학적 안정성을 가져야 한다. 막접촉기 공정에서 분리막은 기공 크기나 구조에 의 한 선택도를 제공하지는 않지만, 젖음 현상을 방지하고 안 정적인 공정 운전을 위해서는 작고 균일한 기공 크기 유지 가 필수적이다. ${ }^{12)}$

초기의 막접촉기 연구는 성형과 모듈화의 편리성 때문에 주로 고분자 분리막 소재를 활용하여 기술이 개발되어 왔다. 소수성 고분자 중에는 poly propylen $(\mathrm{PP})^{13)}$, poly ethylene $(\mathrm{PE})^{14)}$, poly tetra fluoro ethylene (PTFE) $)^{15)}$ 등이 주로 분리 막 소재로 활용되고 있다.

막접촉기에서 유체 흐름에 따라서 기상과 액상보다 막저 항에 의해 전체 성능이 좌우될 수 있다. 이는 막접촉기 공 정 설계 시, 분리막과 흡수제의 구조 및 특성뿐만 아니라 유체 흐름을 제어한 모듈 구조 고려가 중요함을 나타낸다. 분리막 모듈은 평판형, 나권형, 관형, 중공사형 등이 있으 나, 중공사막은 다른 제형에 비해 단위 부피당 막면적을 극 대화할 수 있고 컴팩트한 모듈 구성이 가능하기 때문에 최 근 가장 주목을 받고 있다. ${ }^{16)}$ 일반적인 중공사막 모듈에서 는 중공사 다발을 일렬로 평행하게 포팅하고, 이때 대부분 의 경우에는 분리막 사이 간격이 불균일한 분포를 갖게 된 다. 따라서 모듈의 심한 유체 편류 및 우회 현상이 발생하 여 물질전달 특성 감소를 야기할 수 있다.

평행 흐름 모듈은 가장 일반적인 모듈 구성으로써 기체 와 액체는 분리막을 기준으로 수평 방향으로 이동하며, 이 때 향류와 병류 흐름이 가능하다. 가장 많은 연구가 이루어 져온 모듈이기 때문에 생산이나 특성 예측에 유리하다. ${ }^{17)}$

$3 \mathrm{M} \mathrm{Liqui-Cel}{ }^{\mathrm{TM}}$ 은 분리막 모듈로써, 중앙 배관(feeder)을 중심으로 poly propylen $(\mathrm{PP})$ 중공사막을 촘촘하게 엮은 형 태이다. 중앙 배관은 유체를 공급하는 역할을 하며, 바이패 스 현상을 최소화하고, 분리막 표면과 수직인 흐름을 형성 시킴으로써 효율을 증가시킬 수 있다. 중공사막 포팅제로
써 내용제성 epoxy (EP) 또는 polyethylene (PE) tube sheet 가 사용되며, 하우징은 분리 목적에 따라 polypropylene (PP), polyvinylidene fluoride (PVDF), $316 \mathrm{~L}$ stainless steel 의 3 가지 형태가 있다. ${ }^{18)}$

Pall Corporation (NY, East Hills, NY)은 초순수 응용 분 야에서 사용되는 Separel ${ }^{\mathrm{TM}}$ (Dainippon Ink and Chemicals의 상표) EFM-530 모듈을 제공한다. 해당 모듈은 비다공성 polyolefin 중공사막을 중앙 피더에 일정한 간격으로 엮어, 피더를 통해 중공사막의 수직 방향으로 유체를 공급한다. 비다공성 중공사막은 진공이나 Sweep gas(질소) 공정에 유 리하며, 산소 등 물에 용해된 기체에 대한 높은 선택성을 제공할 수 있다. 상용화된 막접촉기의 경우 대부분 외산제 품이며 국내에서 상용화되어 활용되고 있는 제품은 소용량 제품을 제외하고 대용량 제품은 전무한 실정이다.

막접촉기에서 막은 분리를 위한 선택성을 제공하는 대신 에 기상과 액상을 분리하고, 물질 전달을 위한 유효 접촉 면적을 증가시키는 역할을 한다. 아울러 흡수제에 의한 높 은 선택도 제공과 동시에 단위 부피당 높은 접촉면적을 통 해 장치 크기를 줄일 수 있는 큰 장점을 가진다. 또한, 기 상과 액상은 독립적으로 제어가 가능하고, 범람, 거품 등의 운전상 문제없이 기체 유속을 늘릴 수 있기 때문에 동일 부피에서 장치의 처리 용량 증가가 가능하다. 단위 모듈의 개수 조절을 통해 접촉 면적을 쉽게 제어할 수 있고, 시스 템 예측이 비교적 수월하기 때문에 공정의 용량을 높여서 적용하는 경우(scale-up)에 유리하다. ${ }^{19)}$

초순수 공정에서 사용되는 막탈기 공정의 경우 독점적으 로 외산제품이 적용되고 있어 국산화가 필요하다. 막접촉 기를 상용화하기 위해 접촉 분리막에 사용되는 분리막 및 모듈, 공정 모델 개발, 그리고 그것을 통합하는 전체 공정 을 개발하는 다양한 연구가 수반되어야 한다. 본 연구에서 는 초순수용 $\mathrm{MDG}$ 공정에서 기존 제품과 국산 제품을 비 교 평가하였다.

\section{2. 연구방법}

\section{1. 실험재료 및 공정}

\subsection{1. 초순수 플랜트 공정 및 계측기 현황}

실증플랜트는 시설용량 $25 \mathrm{~m}^{3} / \mathrm{day}$ 규모이며 처리수의 목 표수질은 반도체급 초순수를 목표로 주요 수질관리 기준으 로는 비저항 $18.2 \mathrm{M} \Omega \cdot \mathrm{cm}$ 이하, 총유기탄소(Total Organic Carbon, TOC) $5.0 \mu \mathrm{g} / \mathrm{L}$ 이하, 용존산소(Dissolved Oxygen, $\mathrm{DO})$ 와 실리카 $1.0 \mu \mathrm{g} / \mathrm{L}$ 이하로 목표수질을 정하였다. 초순 수 공정은 Fig. 1 과 같이 전처리공정, 순수처리공정, 초순수 처리공정으로 구성되며, 전처리공정은 탁질을 제거하기 위 한 공정으로 모래여과, 막여과 등의 공정이 있다. 순수 및 초 순수 공정은 이온 및 유기물, 가스제거를 위한 공정으로 이 
Table 1. List of water-sensors for the monitoring of ultrapure water quality measurement.

\begin{tabular}{|c|c|c|c|c|c|c|}
\hline Process & Location & Analyzers & Maker & Model & Parameters & Range \\
\hline \multirow{4}{*}{$\begin{array}{l}\text { Pre- }^{-} \\
\text {treatment } \\
\text { process }\end{array}$} & \multirow{2}{*}{$\begin{array}{l}\text { Cation } \\
\text { ion-ex. }\end{array}$} & $\mathrm{Na}$ & Mettler Toledo & $2300 \mathrm{Na}$ & $\mathrm{Na}$ & $0.001-100,000(\mu \mathrm{g} / \mathrm{L})$ \\
\hline & & $\mathrm{pH}$ & Mettler Toledo & M300 & $\mathrm{pH}$ & $0-14$ \\
\hline & \multirow{2}{*}{$\begin{array}{l}\text { Anion } \\
\text { ion-ex. }\end{array}$} & Conductivity & Mettler Toledo & M300 & Conductivity & $0.02-50,000(\mu \mathrm{s} / \mathrm{cm})$ \\
\hline & & TOC & Sivers & 900 TOC & TOC & $0.03-50(\mathrm{mg} / \mathrm{L})$ \\
\hline \multirow{7}{*}{$\begin{array}{c}\text { Pure water } \\
\text { process }\end{array}$} & \multirow{3}{*}{$\begin{array}{c}\text { RO } \\
\text { (Reverse } \\
\text { Osmosis) }\end{array}$} & Silica & Hach & 5500 & Silica & $0.5-5,000(\mu \mathrm{g} / \mathrm{L})$ \\
\hline & & TOC & Sivers & 900 TOC & TOC & $0.03-50(\mathrm{mg} / \mathrm{L})$ \\
\hline & & Conductivity & Mettler Toledo & M300 & Conductivity & $0.02-50,000(\mu \mathrm{s} / \mathrm{cm})$ \\
\hline & VDG/MDG & DO & Mettler Toledo & M300 & DO & $0-10,000(\mu \mathrm{g} / \mathrm{L})$ \\
\hline & \multirow{3}{*}{$\begin{array}{c}\text { MB/EDI/ } \\
\text { MDI }\end{array}$} & Conductivity & Mettler Toledo & M300 & Conductivity & $0.02-50,000(\mu \mathrm{s} / \mathrm{cm})$ \\
\hline & & Silica & Hach & 5000 & Silica & $0-5,000(\mu \mathrm{g} / \mathrm{L})$ \\
\hline & & Boron & Sivers & UPW boron & Boron & $0.015-20(\mu \mathrm{g} / \mathrm{L})$ \\
\hline \multirow{7}{*}{$\begin{array}{l}\text { Ultrapure water } \\
\text { process }\end{array}$} & AP & Conductivity & Mettler Toledo & M300 & Conductivity & $0.02-50,000(\mu \mathrm{s} / \mathrm{cm})$ \\
\hline & $\mathrm{MP} / \mathrm{CP}$ & Conductivity & Mettler Toledo & M300 & Conductivity & $0.02-50,000(\mu \mathrm{s} / \mathrm{cm})$ \\
\hline & MDG & DO & Mettler Toledo & M300 & DO & $0-10,000(\mu \mathrm{g} / \mathrm{L})$ \\
\hline & \multirow{4}{*}{ UF } & Conductivity & Mettler Toledo & M300 & Conductivity & $0.02-50,000(\mu \mathrm{s} / \mathrm{cm})$ \\
\hline & & TOC & Sivers & Check point & TOC & $0.05-1,000(\mu \mathrm{g} / \mathrm{L})$ \\
\hline & & Particle & Rion & XP-L4A1 & $0.05,0.1,0.15,0.2 \mu \mathrm{m}$ & $0-1,000(\mathrm{ea} / \mathrm{mL})$ \\
\hline & & Particle & PMS & M50e & $0.05,0.1,0.15,0.2 \mu \mathrm{m}$ & $0-10,000(\mathrm{ea} / \mathrm{mL})$ \\
\hline
\end{tabular}

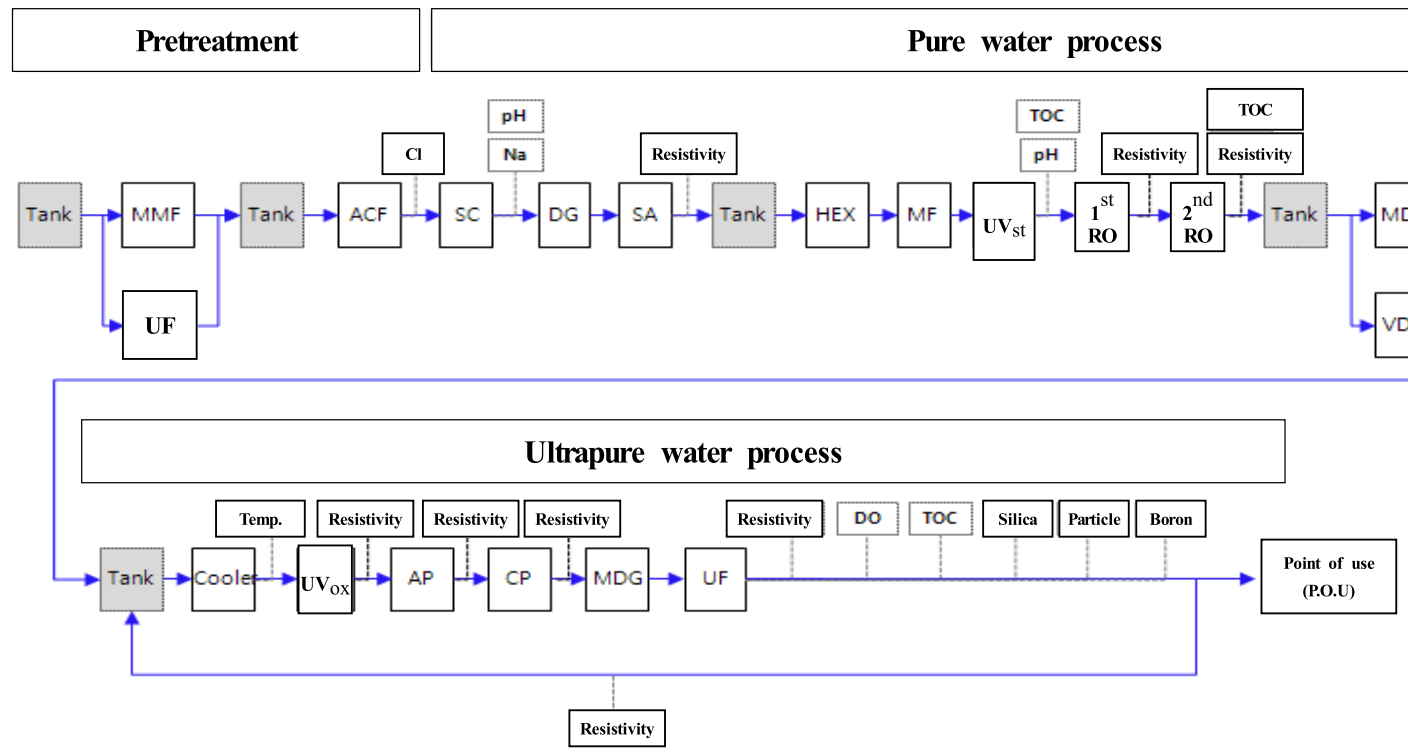

Fig. 1. Schematic diagram and water quality monitoring parts of pilot-scale ultrapure water production plant.

* MMF : Multi Media Filter, MF : Membrane Filtration, ACF : Active Carbon Filter, DG : DeGasffier, SC : Strong Cation Exchanger, SA : Strong Anion Exchanger, $\mathrm{UV}_{\mathrm{st}}$ : Ultraviolet sterilizer, $\mathrm{UV}_{\mathrm{ox}}$ : Ultraviolet oxidation, HEX: Heat EXchanger, VDG : Vacuum DeGasffier, MDG : Membrane DeGasffier, MB : Mixed Bed ion Exchanger, EDI : Electro Delonization, AP : Anion Polisher, CP : Cation Polisher, UF : Ultra Filtration

온교환공정, 자외선산화공정, 탈기공정으로 구성되어 있다. ${ }^{20)}$

운영되고 있는 초순수 플랜트는 2012년에 구축되었으며, 2013 2016년(4년)까지 24시간 중단없이 운영하였다. 원수 는 대청댐에서 취수되며 혼화-응집-침전-여과 공정을 거쳐 여과수가 공급된다. 수질을 평가하기 위하여 실증시설에 수
질측정을 위한 계측기가 설치되었으며, 초순수 파일럿 플랜 트의 각 공정 계측기 설치 현황은 Fig. 1 과 같이 초순수 생 산 후 목표 수질 관리를 위해 비저항, TOC (Total Organic Carbon), DO (Dissolved Oxygen), 입자(Particle), 실리카, 보 론 등의 계측기를 설치하여 실시간으로 모니터링이 가능하 
Table 2. Properties comparison of membrane contactor (3M Liqui-Cel ${ }^{\mathrm{TM}}$ vs Domestic MDG membrane).

\begin{tabular}{|c|c|c|}
\hline Items & $3 \mathrm{M}$ Liqui-Cel $^{\mathrm{TM}}$ & Domestic MDG membrane \\
\hline Membrane formation & Stretching after melt spinning & Thermally Induced Phase Separation \\
\hline Pore structure & Slit shape (instable in process) & Network structure \\
\hline Packing density of hollow fiber in module (\%) & $100 \%$ & $80 \sim 90 \%$ of Liqui-Cel ${ }^{\top \mathrm{M}}$ 's module \\
\hline Material/Type & PP/HFM (Hallow fiber membrane) & PP/HFM (Hallow fiber membrane) \\
\hline \multicolumn{3}{|l|}{ Morphology } \\
\hline ID/OD (um) & $270 / 329$ & $330 / 600$ \\
\hline Thickness ( $\mu \mathrm{m})$ & 29.5 & 135.0 \\
\hline Pore size $(\mu \mathrm{m})$ & 0.03 & 0.2 \\
\hline Porosity (\%) & 20 & 60 \\
\hline Breakthrough pressure (bar) & 6 & 4.3 \\
\hline
\end{tabular}
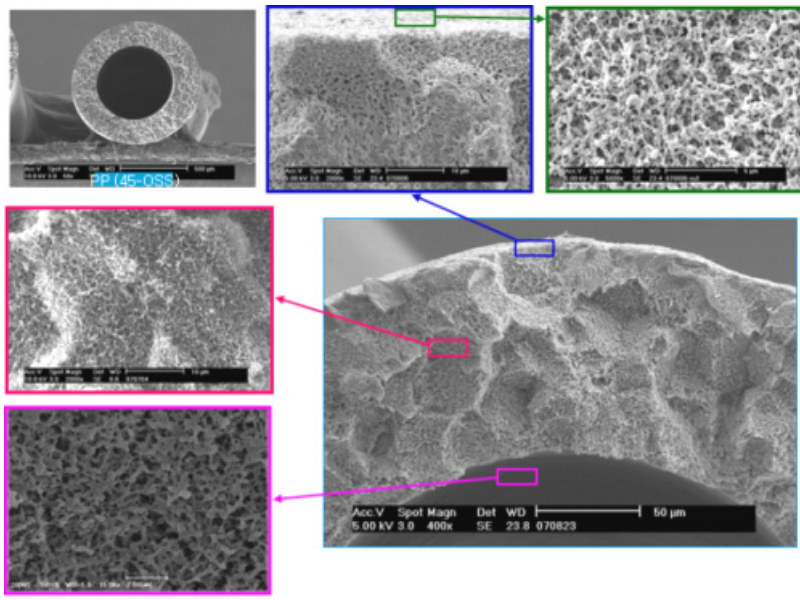

Fig. 2. Hollow fiber membrane for membrane contactor (domestic membrane contactor).
도록 구성하였다. 계측기의 종류 및 사양에 대해서는 Table 1 과 같다.

\subsubsection{MDG 막의 제조 및 제품 비교}

초순수 파일럿 플랜트에 비교 평가를 위해 적용된 막탈기 공정은 $3 \mathrm{M} \mathrm{Liqui-Cel}{ }^{\mathrm{TM}}$ 제품과 국산화 제품으로 제조된 소 수성의 $\mathrm{PP}$ 재질의 $\mathrm{MDG}$ 막이다. 두 가지 막에 대한 물성치는 Table 2와 같다. 멤브레인 제조방식은 $3 \mathrm{M}$ 의 경우 스트레칭 (Stretching) 방식이고, 국산막은 TIPS (Thermally Induced Phase Separation)방식이다. 기공률은 국내 막이 우수하며 이는 막의 확대 사진을 보더라도 막의 분포도가 균일한 것을 확인할 수 있다. 반면 젖음 한계압력은 $3 \mathrm{M}$ 이 $6 \mathrm{bar}$ 로 우수하 며, 막의 사이즈와 Packing density도 $3 \mathrm{M}$ 이 우수하다. 막의 두께도 $3 \mathrm{M}$ 이 더 얇다. 막의 물성치만으로 막 자체의 항목별

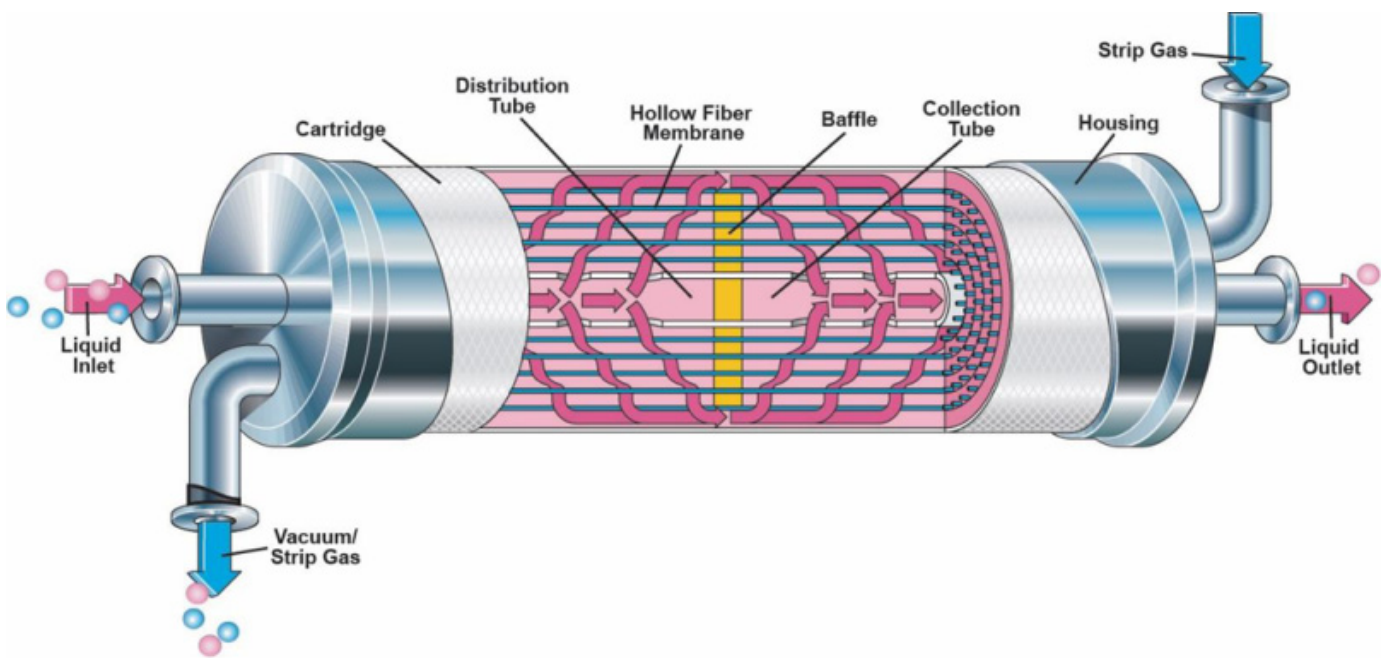

Fig. 3. Design\&Operating guideline for Liqui-Cel $(\mathbb{R}$ extra-flow [18]. 


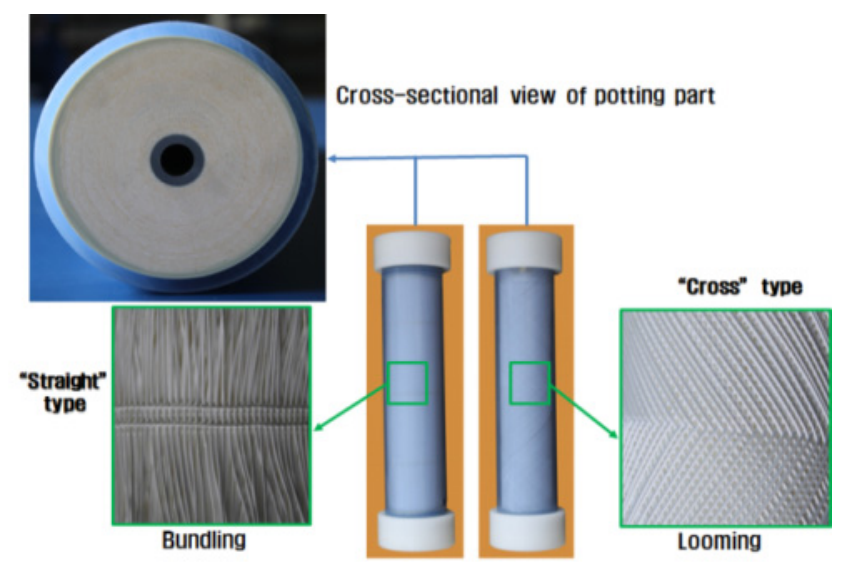

Fig. 4. Membrane module of domestic membrane contactor.

장단점은 파악이 가능하나 용존산소의 제거성능을 파악하 기는 어렵다.

\subsection{3. 막접촉기 모듈}

$\mathrm{MDG}$ 모듈은 중공사막을 하우징 내부에 설치하여 액체 와 기체가 분리될 수 있도록 아래 Fig.3과 같은 구조를 갖 는다. 초순수에 사용되는 탈기공정은 중공사막의 외부에서 초순수가 들어가고 나오도록 되어 있고, 내부는 질소가스 를 공급하여 진공펌프를 통해 진공을 형성한다. 또한, 내부 는 중공사막과 유체가 수직으로 접촉될 수 있도록 하여 접 촉 효율을 높이고 중간에 Baffle을 통해 중간 파이프로 회 수될 수 있도록 한다.

국산막 모듈의 구조도 Fig. 4와 같이 동일하게 구성하였 으며, 내부 막의 패킹은 Looming방식을 적용하여 패킹율을 높였다. 중공사막을 4인치 내경의 Chlorinated Polyvinyl Chloride (C-PVC) 튜브 케이스에 장착하여 Epoxy (EP)로 케이스 양쪽 끝을 포팅한 후 절단하여 C-PVC 캡을 씨워 막 모듈을 제조하였다. 막모듈의 유효 막면적은 약 $10 \mathrm{~m}^{2}$ 이다.

\subsection{4. 막접촉기의 운전 조건}

$\mathrm{MDG}$ 에서 $\mathrm{DO}$ 는 액체, 분리막, 기체의 3 가지 저항을 거 쳐 제거된다. $\mathrm{DO}$ 가 분리막을 통해 제거되는 메커니즘은 Resistance in series 이론으로 설명할 수 있다. 특히 정상 상태에서의 분리막 기공을 통한 $\mathrm{DO}$ 의 이동은 식 1 과 같이 표현된다.

$$
J_{O_{2}}=K_{L}\left(C_{O_{2}}-C_{O_{2}}^{*}\right)
$$

Eq. 1

$J_{O_{2}}: \mathrm{O}_{2}$ absorption flux $\left(\mathrm{mol} / \mathrm{m}^{2} \cdot \mathrm{s}^{-1}\right)$

$K_{L}$ : Overall mass transfer coefficient $(\mathrm{m} / \mathrm{s})$

$C_{\mathrm{O}_{2}}: \mathrm{O}_{2}$ Concentration in solution $\left(\mathrm{mol} / \mathrm{m}^{3}\right)$

$C_{O_{2}}^{*}: \mathrm{O}_{2}$ Concentration in equilibrium $\left(\mathrm{mol} / \mathrm{m}^{3}\right)$
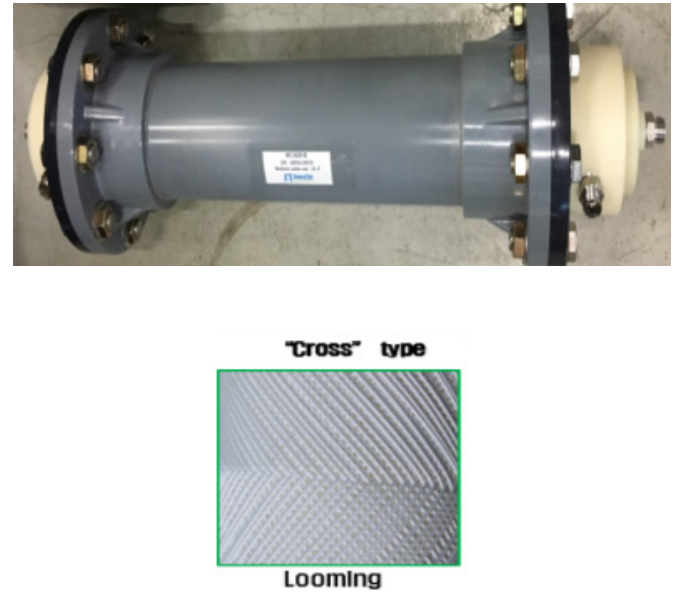

식 1 에서 $\mathrm{O}_{2}$ 이동에 대한 접촉막 공정에서 총괄 물질전달 계수는 공정 효율을 분석하기 위한 기본적이고 핵심적인 인자이다. Resistance in series 이론을 통해 전체 저항은 액 체, 기체, 막의 저항으로 구분할 수 있으며 $\mathrm{MDG}$ 공정에서 기상은 진공상태이므로 저항이 없다고 가정하면 식 2 와 같다.

$$
R_{T}=R_{m}+R_{l}
$$

Eq. 2

$R_{T}:$ Resistance in total

$R_{m}$ : Resistance in membrane

$R_{l} \quad$ : Resistance in liquid

저항은 물질전달계수와 반비례관계로 총괄 물질전달저항 은 액상, 분리막, 기상의 개별 물질전달저항의 합으로 구할 수 있으며, $\mathrm{MDG}$ 공정에서 기상은 진공상태로 저항이 없 다고 가정하면 식 2 를 아래 식 3 과 같이 나타낼 수 있다.

$$
\frac{1}{K_{L}}=\frac{1}{k_{m}}+\frac{1}{k_{l}}
$$

$K_{L} \quad$ : Overall mass transfer coefficient $(\mathrm{m} / \mathrm{s})$

$k_{m}$ : Mass transfer coefficient of membrane $(\mathrm{m} / \mathrm{s})$

$k_{l}:$ Mass transfer coefficient of liquid $(\mathrm{m} / \mathrm{s})$

본 연구에서는 $\mathrm{MDG}$ 막으로 소수성 중공사를 사용하였으 며 $\mathrm{MDG}$ 막에서 $\mathrm{DO}$ 의 제거프로세스는 세 단계로 구성된 다. $\mathrm{MDG}$ 공정에서 총물질전달 저항은 기상, 분리막, 액상 저항으로 구성되며, 물질전달 원리는 Fig. 5와 같다. ${ }^{21)}$

기체와 액체 사이 분리막의 기공은 기체 또는 액체로 채 워질 수 있으며, 이에 따른 물질전달 특성이 변화하게 된 다. 분리막 기공이 액체로 채워지게 되면, 물질전달 저항이 커지게 되고, 장기적으로 기공이 변형될 수 있다. 따라서, 효율을 높이고 안정적인 운전을 위해서는 분리막 기공이 기체로 채워져야 한다. 접촉막 공정의 운전에는 Fig. 6과 


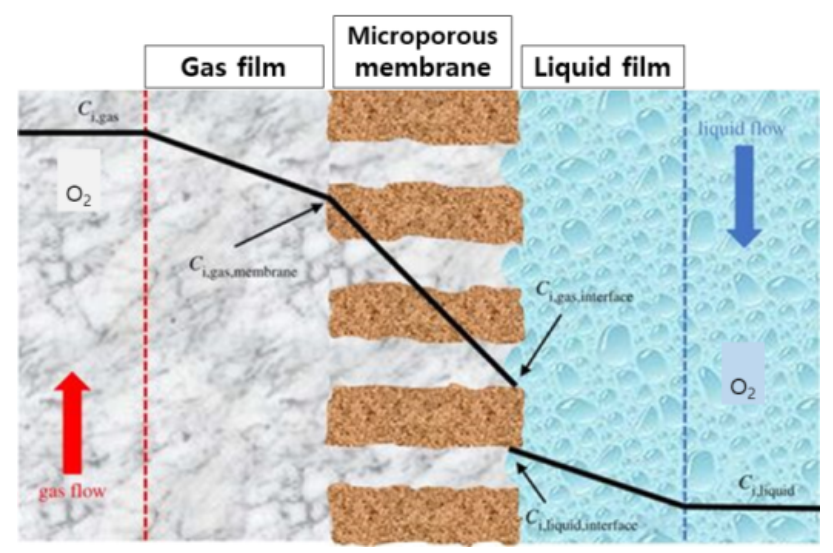

Fig. 5. Mass transfer mechanism of membrane contactor. ${ }^{21)}$

같이 비젖음(non-wetted, gas filled pores) 모드, 부분 젖음 (partially wetted) 모드, 젖음(totally wetted) 모드의 3 가지가 존재한다. 비젖음 모드로 운전 시 물질전달 특성을 높일 수 있어 선호되며, 젖음 모드에 비해 약 6 배 높은 물질전달계 수를 얻을 수 있음이 보고되었다. 따라서 비젖음 모드로 운 전하는 것이 중요하다.

분리막의 젖음은 막 기공사이즈와 관련이 있으며 기공사 이즈가 크면 액체의 누수가 발생하고 이는 기체 제거효율 을 낮게 한다. 분리막 젖음 현상은 다음의 식 4로 최소침투 압력(breakthrough pressure)을 계산하여 예측할 수 있다. ${ }^{22)}$

$$
\Delta P_{\text {break }}=\frac{4 \beta \gamma \cos (\theta)}{d_{p^{\max }}}
$$

Eq. 4

$\triangle P_{\text {break }}$ : Minimum breakthrough pressure (MPa)

$\beta \quad$ : Geometric factor used for non-cylindrical pores (-)

$\gamma \quad$ : Liquid surface tension (dyn/cm)

$\theta \quad$ : Liquid-membrane contact angle $\left({ }^{\circ}\right)$

$d_{p^{\max }} \quad$ : Largest pore size $(\mu \mathrm{m})$

분리막을 기준으로 액체측의 공급압력이 $\Delta \mathrm{P}_{\text {break }}$ 보다 높 을 때는 막의 젖음현상이 발생한다. 이상적인 조합은 표면 장력이 높은 흡수 액체 및 높은 소수성을 갖춤으로 높은
접촉각을 갖는 막의 조합이다. 기공의 사이즈는 작으면서 높은 질량 전달 계수를 유지하면 누수를 방지할 수 있다. 결과적으로, 액체의 공급압력이 낮으면서 소수성막으로 기 공의 사이즈가 낮고 기공률이 높은 특성을 갖춘 막이 효율 이 높다고 할 수 있다.

\subsection{5. 실험공정}

본 연구에서 신규 $\mathrm{MDG}$ 막 모듈의 성능 검증을 위해 아 래 Fig.7과 같이 공정을 구성하였다. 기존공정은 Polisher, $\mathrm{MDG}$ liqui-cel ${ }^{\mathrm{TM}}$ ), Final UF 공정 순서이며, $\mathrm{DO}$ 계측기는 $\mathrm{MDG}$ 전/후단에서 측정 가능하도록 샘플링 배관을 구성하 였다. $\mathrm{MDG}$ 공정은 질소가스를 주입하고 진공펌프로 진공 만든다. 신규 $\mathrm{MDG}$ 막 모듈은 기존 $\mathrm{MDG}$ 와 비교가 가능하 도록 배관을 구성하였다. 기존 $\mathrm{MDG}$ 공정과 신규 국내 $\mathrm{MDG}$ 공정을 선택할 수 있도록 Fig.7과 같이 구성하였다.

\section{2. 평가 방법}

\subsection{1. 개요}

국산 $\mathrm{MDG}$ 막은 석유화학공정 중 $\mathrm{CO}_{2}$ 가스 공정에서 사 용되는 중공사막으로 초순수 공정에 적용이 가능하도록 개 량하여 모듈을 개발하였다. 국산 $\mathrm{MDG}$ 막의 개발에 따른 평가방법으로 중공사막 및 모듈에 대한 성능 평가를 구분 하여 실시하였다. 우선, 중공사막의 평가를 위해 조건(진공 도, 질소가스 주입량)에 따른 $\mathrm{DO}$ 제거율을 평가하였다. $\mathrm{DO}$ 제거율은 두 $\mathrm{MDG}$ 막을 이용하여 질소농도와 진공도를 각각 $2.5 \sim 5 \mathrm{~L} / \mathrm{min}$ 및 $30 \sim 150 \mathrm{mmHg}$ 로 변화시키며 평가 하였다.

중공사막에 대한 평가뿐만이 아니라 모듈 평가를 위해 국 산 $\mathrm{MDG}$ 모듈 설치 및 배관을 구성하였다. 비재생형 이온 교환수지 후단에 배관을 수정하여 국산화 $\mathrm{MDG}$ 를 설치하 였으며, 최초 설치 후 유기물에 대한 용출평가를 실시하였 으며, 유기물은 Total organic carbon (TOC)로 측정하였다. $\mathrm{DO}$ 제거효율을 평가하기 위해 $\mathrm{MDG}$ 공정 전단과 후단에 $\mathrm{DO}$ 계측기를 설치하여 분석하였다. 초순수 최종 DO 보증 수질은 $1 \mu \mathrm{g} / \mathrm{L}$ 이하이다. 일반적인 초순수 공정에서 $\mathrm{MDG}$

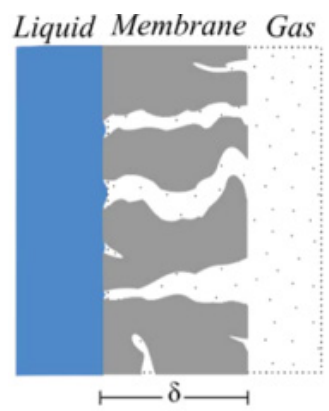

(a) Gas filled pores

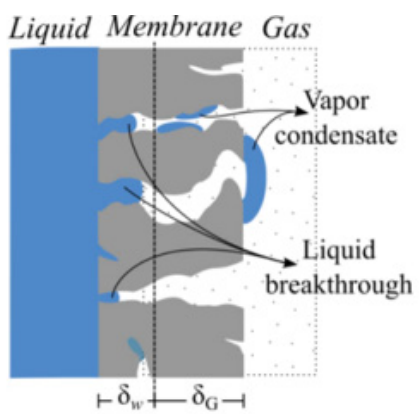

(b) Partially wetted

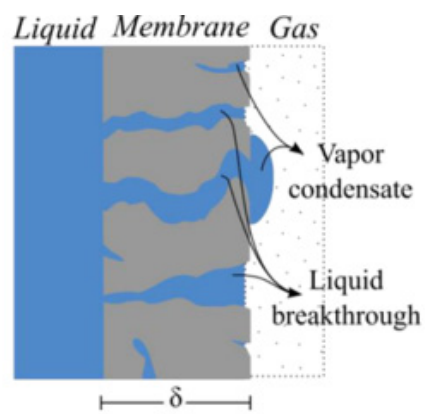

(c) Totally wetted

Fig.6. States of microporous membrane wetting. 


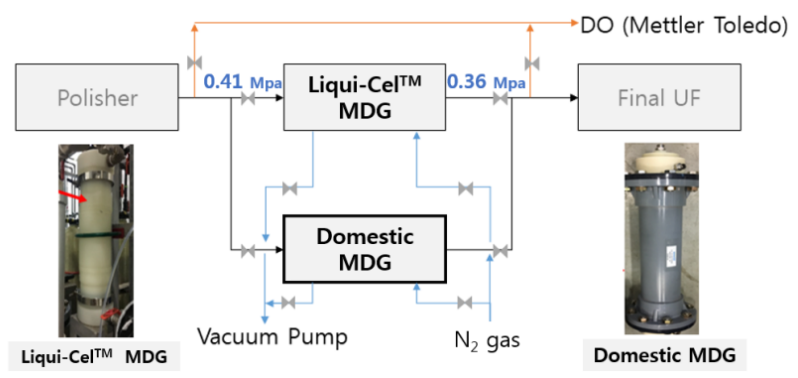

Fig. 7. Process diagram of MDG for the test.

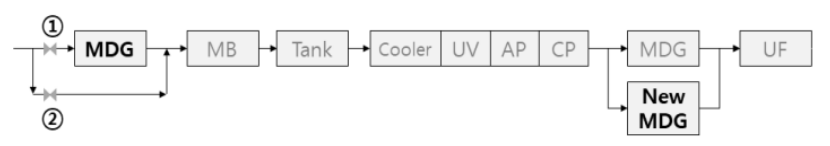

Fig. 8. Process diagram of MDG $\Pi$.

전단 $\mathrm{DO}$ 농도는 $10 \mu \mathrm{g} / \mathrm{L}$ 이하이며 정상상태로 제거율을 평가하였다. 또한, DO $100 \sim 500 \mu \mathrm{g} / \mathrm{L}$ 의 고농도에서의 실 험을 위해 순수공정(RO후단) $\mathrm{MDG}$ 바이패스 밸브의 개도 율을 조절하여 $\mathrm{DO}$ 농도를 조절하여 제거율을 평가하였다. 또한, 운전조건인 진공도, $\mathrm{LN}_{2}$, 공급압력을 조절하여 비 교·평가하였다. 측정에 사용된 TOC 계측기는 Sivers사의 Check point이며, $0.05 \sim 1000 \mu \mathrm{g} / \mathrm{L}$ 까지 측정이 가능하다. 또한, DO 계측기는 Mettler Toledo, M300으로 $0 \sim 10,000 \mu \mathrm{g} / \mathrm{L}$ 까 지 측정이 가능하다.

\subsection{2. 신규 $\mathrm{MDG}$ 성능평가 및 인입수 $\mathrm{DO}$ 농도조절}

초순수 $\mathrm{MDG}$ 공정은 $\mathrm{MDG}$ 모듈에서의 유기물 용출이 없 어야 하며, 빠른 시간 내에 수질이 정상적으로 회복되어 공 급이 되어야 한다. 이를 위해 신규 $\mathrm{MDG}$ 막으로 유기물 용 출에 따른 회복 시간을 측정하였다. 그리고, 초순수의 인입 수 DO 농도조절을 위해 Fig.9와 같이 순수 $\mathrm{MDG}$ 공정의 바이패스 밸브를 조절하여 농도를 조절한다. 일반적인 공 정 조건에서의 성능평가를 위해 Fig.8에서 (2)번 밸브를 닫 으면 초순수 $\mathrm{MDG}$ 공정의 용존산소 인입수 농도가 $3 \mu \mathrm{g} / \mathrm{L}$ 수준이며 이를 $1 \mu \mathrm{g} / \mathrm{L}$ 이하로 제거하여야 한다. 초순수 공 정 인입수의 DO 농도는 (2)번 밸브의 개·폐를 통해 조절하 였다.

\subsection{3. 신규 $\mathrm{MDG}$ 의 진공도(Vacuum), Sweep gas $\left(\mathrm{LN}_{2}\right)$ 조절, 공급압력 $(\mathrm{MPa})$ 조절}

Fig. 10과 같이 $\mathrm{MDG}$ 의 진공도를 조절하는 라인에 공기 주입 밸브를 달아 공기를 주입시켜 진공도를 조절하였다. Sweep gas 조절은 오염된 물질을 불어 제거하기 위한 공정 으로 Fig. 11의 밸브를 조절하여 Sweep gas로 사용한 $\mathrm{LN}_{2}$ (액체질소)의 공급량을 $0 \mathrm{Nm}^{3} / \mathrm{h}, 0.2 \mathrm{Nm}^{3} / \mathrm{h}, 0.4 \mathrm{Nm}^{3} / \mathrm{h}$ 의 3 단계로 조절 $\left(0.2 \mathrm{Nm}^{3} / \mathrm{h}\right.$ 정상상태 $)$ 하여 관찰하였다. 또한,

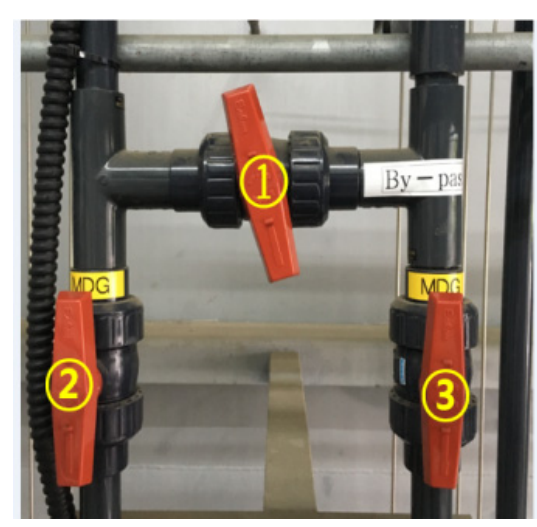

Fig. 9. Inlet concentration control valve (1) By-pass valve, (2) (3) MDG in\&out valve).

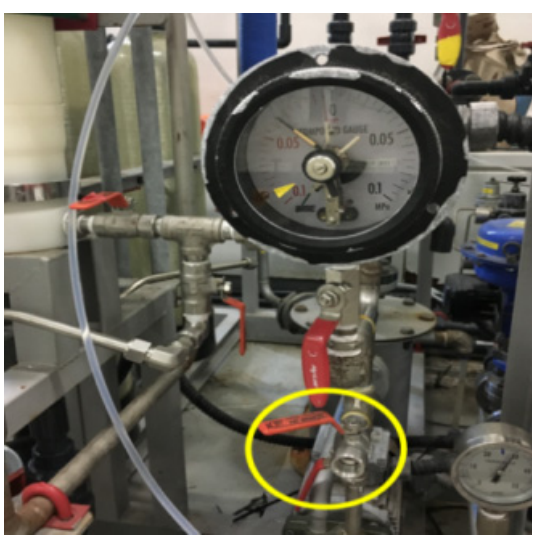

Fig. 10. Vacuum control valve.

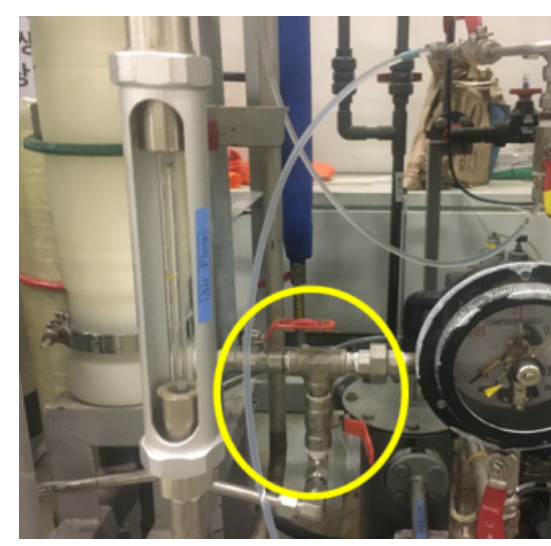

Fig. 11. Sweep gas $\left(\mathrm{LN}_{2}\right)$ control valve.

동일한 유량조건에서 초순수 공급압력의 조절을 위해 후단 Pressure control valve (PCV)를 조절하였다.

\section{3. 결과 및 고찰}

\section{1 중공사막 평가결과}

중공사막에 대한 물성평가를 위해 진공모드와 콤보모드(진 공압력유지와 질소가스공급)에서 평가를 시행하였다. 진공모 드는 질소가스의 공급없이 진공도를 $30 \mathrm{mmHg}, 90 \mathrm{mmHg}$, 

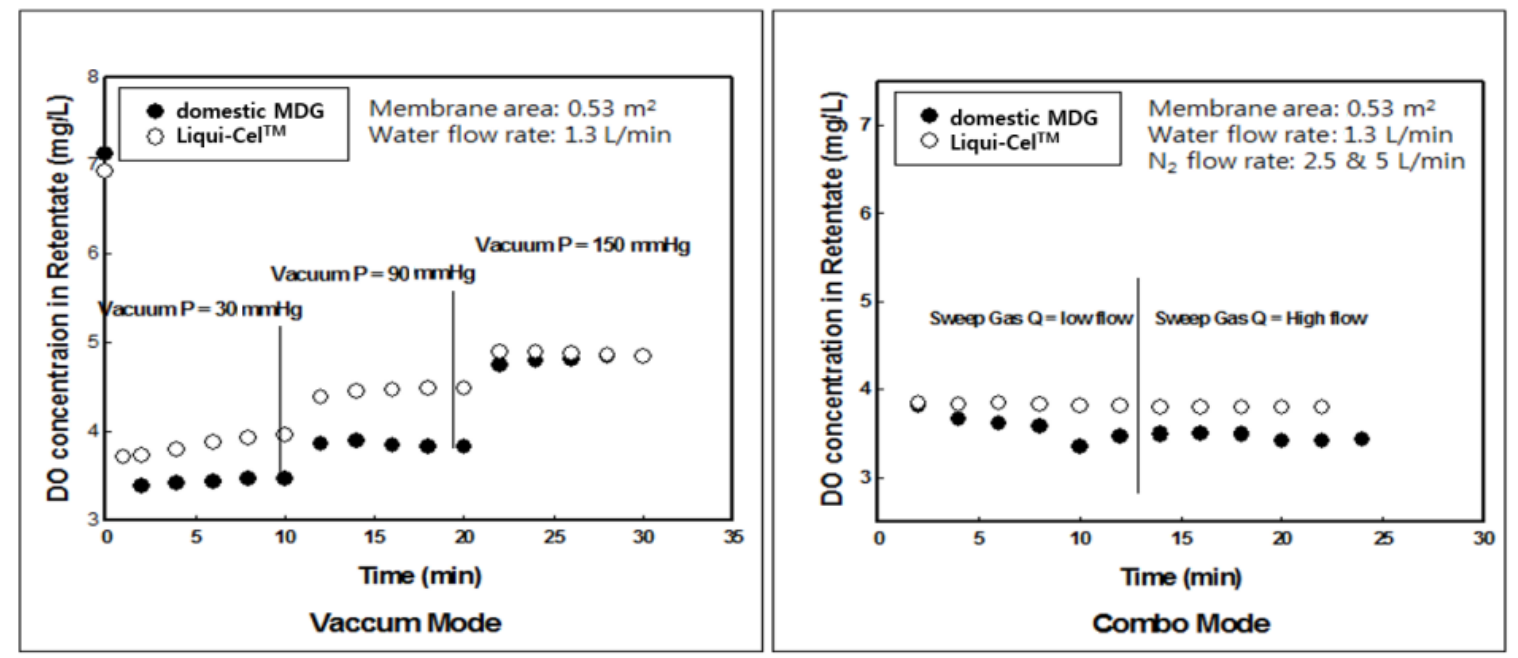

Fig. 12. Dissolved oxygen (DO) removal from tap water with permeating time (Vacuum mode and Combo mode (vacuum + sweep gas)) (a) at various vacuum pressure, and (b) at various sweep rate of $\mathrm{LN}_{2}$.

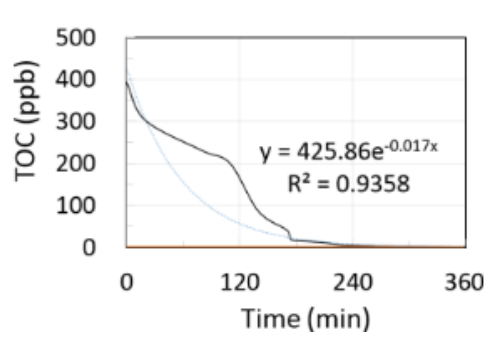

1st MDG membrane

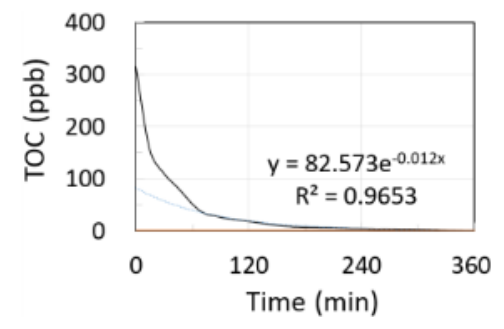

2nd MDG membrane

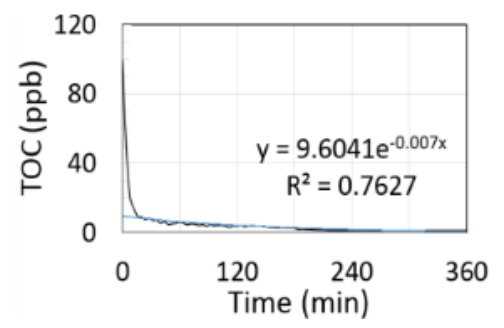

3rd MDG membrane

Fig. 13. Changes in dissoluted TOC from domestic MDG modules at various trials.

$150 \mathrm{mmHg}$ 조건에서 $\mathrm{DO}$ 제거율 평가하였으며, 콤보모드는 진공상태에서 질소가스를 $2.5 \mathrm{~L} / \mathrm{min}, 5 \mathrm{~L} / \mathrm{min}$ 로 조정하여 $\mathrm{DO}$ 제거율을 평가하였다. 진공모드 및 콤보모드에 대한 $\mathrm{DO}$ 제거율 평가 결과는 Fig. 12와 같다.

진공모드에서 진공도를 각각 $30 \mathrm{mmHg}, 90 \mathrm{mmHg}, 150$ $\mathrm{mmHg}$ 조건으로 변경한 경우 Liqui-cel ${ }^{\mathrm{TM}}$ 막의 경우 각각 3.8 $\mathrm{mg} / \mathrm{L}, 4.4 \mathrm{mg} / \mathrm{L}, 4.9 \mathrm{mg} / \mathrm{L}$ 이며, 국내 중공사막 각각 3.4 $\mathrm{mg} / \mathrm{L}, 4.0 \mathrm{mg} / \mathrm{L}, 4.8 \mathrm{mg} / \mathrm{L}$ 로 국내 중공사막의 $\mathrm{DO}$ 농도가 더 낮은 수준이었다. 콤보모드의 실험시 진공상태에서 질소가스 를 $2.5 \mathrm{~L} / \mathrm{min}$ 로 조정하여 $\mathrm{DO}$ 농도를 측정한 결과 $\mathrm{Liqui}_{-\mathrm{Cel}^{\mathrm{TM}}}$ 막 $3.8 \mathrm{mg} / \mathrm{L}$, 국내 중공사막 $3.5 \mathrm{mg} / \mathrm{L}$ 이었다. 질소가스를 5 $\mathrm{L} / \mathrm{min}$ 로 조정하였을 경우 $\mathrm{DO}$ 농도가 Liqui-cel $^{\mathrm{TM}}$ 막 3.8 $\mathrm{mg} / \mathrm{L}$ 이며, 국내 중공사막의 경우 $3.4 \mathrm{mg} / \mathrm{L}$ 로 국내 중공사 막의 DO 농도가 더 낮은 수준이었다. 이는 초순수급이 아닌 순수급 정도의 DO 농도에 대한 평가이다. 초순수의 경우 4.9 $\sim 3.4 \mathrm{mg} / \mathrm{L}$ 가 아닌 $0 \sim 500 \mu \mathrm{g} / \mathrm{L}(0 \sim 0.5 \mathrm{mg} / \mathrm{L})$ 로 초순수에 서 평가하는 $\mathrm{DO}$ 농도와는 차이가 있다.

진공모드와 콤보모드 두 가지 경우 모두에서 국내 $\mathrm{MDG}$ 막의 DO 농도가 더 낮은 수준이였다. 이는 liqui-Cel $^{\mathrm{TM}}$ 과 국내 $\mathrm{MDG}$ 중공사막의 Porosity (\%)가 $20 \%$ 와 $60 \%$ 로 차이
가 있으며, 막 기공의 균일도도 국내 MDG막이 Table 2 및 Fig. 2의 막 사진에서 볼 수 있듯이 균일하여 제거효율이 높은 것으로 판단된다. $\mathrm{MDG}$ 공정은 중공사막을 이용하여 모듈을 제작하여 $\mathrm{DO}$ 제거율에 대한 성능평가를 진행하여 야 한다.

\section{2. $\mathrm{MDG}$ 모듈 평가결과}

\subsection{1. 인입수 DO농도에 따른 제거효율}

신규 $\mathrm{MDG}$ 막의 제작시 1차, 2차, 3차 막에 대한 유기물 농출에 대한 시간을 측정한 결과를 Fig. 13에 나타내었다. 초순수 $\mathrm{MDG}$ 공정이 정상상태 $\mathrm{TOC} 0.45 \mu \mathrm{g} / \mathrm{L}$ 가 될 때까지 의 소요시간을 확인하였다. 제작의 차수가 증가할수록 통 수(세척)로 인한 초기 TOC 농도가 낮아지고, 안정화 단계 까지의 소요시간이 줄었다. 1 차 제작품은 최초 모듈제작품 으로 최초 설치하였으나, 인입수 $\mathrm{DO}$ 농도보다 생산수의 $\mathrm{DO}$ 농도가 높아 막의 누기로 인해 외부 공기가 유입되는 것으로 예상되었다. 2 차 제작품은 막의 누기는 개선하였으 나, 외부 하우징에서 초순수의 누수가 발생되어 추가 개선 이 필요하였다. 3 차 제작품은 외부 하우징 누수 방지를 위 해 하우징의 마감을 플랜지 형태로 변경하였으며, 중공사 
Table 3. DO removal rate during normal operation.

\begin{tabular}{cccc} 
& $\begin{array}{c}\text { Inlet DO } \\
(\mu \mathrm{g} / \mathrm{L})\end{array}$ & $\begin{array}{c}\text { Outlet DO } \\
(\mu \mathrm{g} / \mathrm{L})\end{array}$ & $\begin{array}{c}\text { Rejection } \\
(\%)\end{array}$ \\
\hline Liqui-Cel $^{\mathrm{TM}}$ & 3 & 0 & 100 \\
\hline $\begin{array}{c}\text { Domestic MDG } \\
\text { membrane }\end{array}$ & 3 & 0 & 100 \\
\hline
\end{tabular}

Table 4. DO removal rate at the elevated DO concentration.

\begin{tabular}{cccc} 
& $\begin{array}{c}\text { Inlet DO } \\
(\mu \mathrm{g} / \mathrm{L})\end{array}$ & $\begin{array}{c}\text { Outlet DO } \\
(\mu \mathrm{g} / \mathrm{L})\end{array}$ & $\begin{array}{c}\text { Rejection } \\
(\%)\end{array}$ \\
\cline { 2 - 4 } $\begin{array}{c}\text { Domestic MDG } \\
\text { membrane }\end{array}$ & 150 & 52 & 65 \\
\cline { 2 - 4 } & 400 & 155 & 61 \\
\hline
\end{tabular}

막의 패킹 효율을 증가시키기 위해 방법을 개선하였다. 막 제작의 차수가 증가할수록 용출도가 현저하게 짧아지는 것 을 볼 수 있다. 이는 최초 모듈 제작 후에는 세정작업을 하 지 않았으나, 3 차 제작품에서는 TOC 용출도는 낮추기 위 해 순수를 이용하여 세정 작업을 추가하여 나타난 결과로 예상된다.

초순수 시스템이 일반적으로 운영될 경우 Table 3과 같이 인입수 DO농도는 $3 \mu \mathrm{g} / \mathrm{L}$ 이며 생산수의 DO 농도는 $1 \mu \mathrm{g} / \mathrm{L}$ 이하를 만족하여야 한다. 기존의 Liqui-Cel ${ }^{\mathrm{TM}}$ 막의 경우 인 입수 농도가 $3 \mu \mathrm{g} / \mathrm{L}$ 에서 $0 \mu \mathrm{g} / \mathrm{L}$ 까지 $100 \%$ 제거되었다. 신규로 적용된 국내 $\mathrm{MDG}$ 막의 경우도 동일하게 인입수 농도가 $3 \mu \mathrm{g} / \mathrm{L}$ 에서 $0 \mu \mathrm{g} / \mathrm{L}$ 까지 $100 \%$ 제거되어 동일한 성능을 확인할 수 있었다. 인입수 농도가 $3 \mu \mathrm{g} / \mathrm{L}$ 에서는 Liqui-Cel $^{\mathrm{TM}}$ 막과 국내 MDG 막의 성능이 동일한 수준으로 평가되었다.

초순수 공정에서 순수 $\mathrm{MDG}$ 의 바이패스 밸브를 조절하 여 인위적으로 인입수를 $\mathrm{DO}$ 농도를 증가시켰을 경우의 성 능을 확인하기 위해 아래와 같이 DO 농도를 변화시켰다. Table 4에서와 같이 인입 $\mathrm{DO}$ 농도가 증가할 경우 국내 $\mathrm{MDG}$ 막의 경우 $\mathrm{DO}$ 제거율은 $61 \sim 65 \%$ 로 감소하였다. 이는 중공사막의 평가에서 국내 $\mathrm{MDG}$ 중공사막의 효율이 더 높 은 결과와는 상반된다.

중공사막을 이용한 $\mathrm{MDG}$ 모듈의 제작의 경우 가장 중요한 점이 패킹효율이며, 이는 국내 막의 패킹효율은 $\mathrm{Liqui}^{-\mathrm{Cel}^{\mathrm{TM}}}$ 막과 비교하여 $80 \sim 90 \%$ 로 낮은 수준이며, 막의 패킹효율 은 유체의 흐름과도 연관이 있다. 막의 직접도가 높을수록 유체의 흐름과 막이 접촉할 수 있는 공간이 많아짐으로 제 거효율과 연관이 있다. 즉, 직접도가 높을수록 제거효율이 높을 것으로 예상된다.

$\mathrm{MDG}$ 초순수 공급압력이 $0.41 \mathrm{MPa}$ 의 동일 조건에서

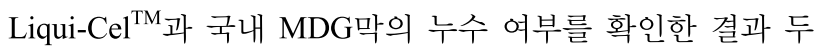
개 모듈에서 누수가 발생하였다. 국내 $\mathrm{MDG}$ 막의 경우 공 극 크기(Pore size)가 $0.2 \mu \mathrm{m}$ 로 최소침투압력이 $0.4 \mathrm{MPa}$ 로
Table 5. Removal rate of DO according to the change of vacuum pressure.

\begin{tabular}{ccccc} 
& $\begin{array}{c}\text { Vacuum pressure } \\
(\mathrm{MPa})\end{array}$ & $\begin{array}{c}\text { Inlet DO } \\
(\mu \mathrm{g} / \mathrm{L})\end{array}$ & $\begin{array}{c}\text { Outlet DO } \\
(\mu \mathrm{gg} / \mathrm{L})\end{array}$ & $\begin{array}{c}\text { Rejection } \\
(\%)\end{array}$ \\
\cline { 2 - 5 } $\begin{array}{c}\text { Domestic } \\
\text { MDG }\end{array}$ & 0 & 260 & 100.2 & 61.5 \\
\cline { 2 - 5 } membrane & 0.035 & 260 & 98 & 62.3 \\
\cline { 2 - 5 } & 0.065 & 260 & 97 & 62.7 \\
\hline
\end{tabular}

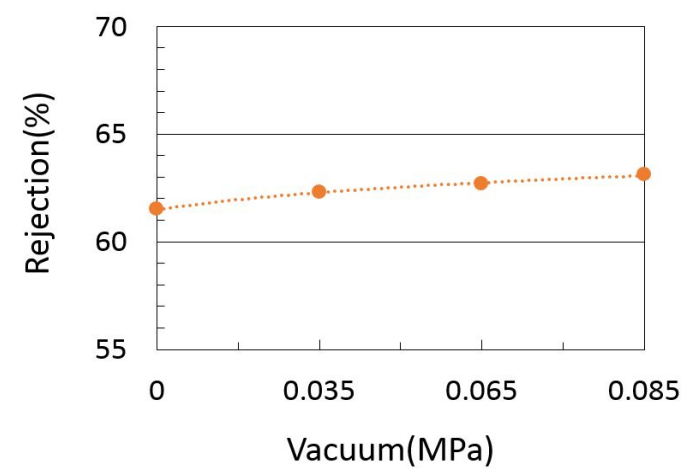

Fig. 14. Removal of DO by domestic MDG membranes at various vacuum pressure.

누수가 예상되었으나, Liqui-Cel ${ }^{\mathrm{TM}}$ 의 경우 공극 크기가 $0.03 \mu \mathrm{m}$ 로 최소침투압력이 $0.6 \mathrm{MPa}$ 로 누수발생이 없을 것 으로 예상되었으나, 누수가 확인되었다. 이는 $\mathrm{Liqui}^{-\mathrm{Cel}^{\mathrm{TM}}}$ 의 공극크기가 $0.03 \mu \mathrm{m}$ 이나, Table 2의 Liqui-Cel ${ }^{\mathrm{TM}}$ 막의 기공 분포에서 보는 바와 같이 분포도가 넓어서 최소침투 압력이 $0.6 \mathrm{MPa}$ 인데도 불구하고 누수가 발생한 것으로 보 인다.

\subsection{2. 진공도의 영향}

초순수 공정이 정상적으로 운영이 되는 진공도 $0.085 \mathrm{MPa}$ 를 포함한 $0 \mathrm{MPa}, 0.035 \mathrm{MPa}, 0.065 \mathrm{MPa}, 0.085 \mathrm{MPa}$ 총 4단계 로 제거율 거동을 관찰하였다. 진공도가 낮을수록 제거율 이 줄어드나, 그 값의 변화는 크지 않았다. 진공도와 제거 율의 상관관계를 Table 5 및 Fig. 14에 나타내었다.

정상 상태에서의 분리막 기공을 통한 $\mathrm{DO}$ 의 이동은 앞서 언 급된 바와 같이 식 $1\left(J_{O_{2}}=K_{L}\left(C_{O_{2}}-C_{O_{2}}^{*}\right)\right.$ )과 같이 표현된 다. 즉, 식 1 은 $\mathrm{O}_{2}$ 이동(탈기)속도 $\left(J_{O_{2}}\right)$ 는 농도차이 $\left(C_{O_{2}}-C_{O_{2}}^{*}\right)$ 에 비례한다. 그리고, 여기서 농도차이는 물속의 $\mathrm{O}_{2}$ 농도와 진공상태의 $\mathrm{O}_{2}$ 의 차이를 나타낸다. 진공상태의 $\mathrm{O}_{2}$ 농도는 진 공도가 증가할수록 진공상태의 $\mathrm{O}_{2}$ 농도는 감소함으로 진공 도의 증가는 농도차이를 커지게 만들어 이동속도를 크게 한 다. 즉, 진공도가 증가할수록 이동속도가 빨라져서 $\mathrm{O}_{2}$ 제거 율은 높아지게 된다.

Table 5 및 Fig. 14에서와 같이 진공도가 $0 \sim 0.085 \mathrm{MPa}$ 로 
Table 6. Removal rate of DO according to $\mathrm{LN}_{2}$ flow rate.

\begin{tabular}{ccccc}
$\mathrm{LN}_{2}$ flow rate & $\begin{array}{c}\text { Inlet DO } \\
\left(\mathrm{Nm}^{3} / \mathrm{h}\right)\end{array}$ & $\begin{array}{c}\text { Outlet DO } \\
(\mu \mathrm{L} / \mathrm{L})\end{array}$ & $\begin{array}{c}\text { Rejection } \\
(\%)\end{array}$ \\
$\begin{array}{c}\text { Domestic } \\
\text { MDG }\end{array}$ & 0 & 260 & 115.3 & 56 \\
\cline { 2 - 5 } membrane & 0.2 & 260 & 96 & 63.1 \\
\cline { 2 - 5 } & 0.4 & 260 & 95.5 & 63.3 \\
\hline
\end{tabular}

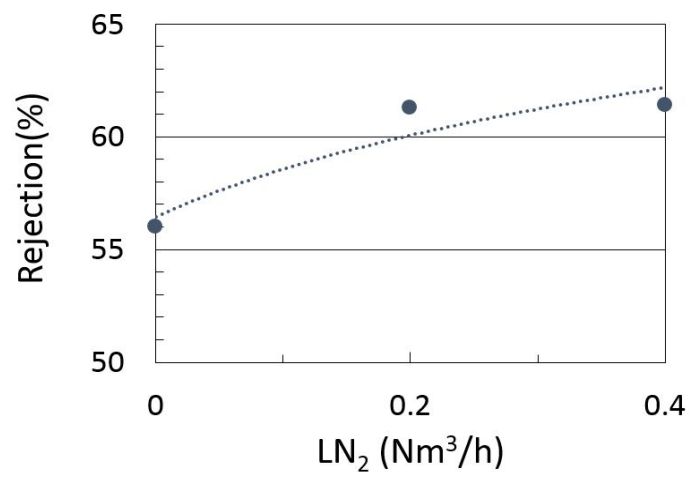

Fig. 15. Performance evaluation by sweep gas $\left(\mathrm{LN}_{2}\right)$.

증가하면 제거율은 $61.5 \sim 63.1 \%$ 로 $1.6 \%$ 가 증가함으로 위 에서 설명한 식 1 과 같은 실험결과이다. 그러나 진공도의 변화폭과 비교하여 제거율은 $1.6 \%$ 만큼 변화하여 변화폭이 크다고 볼 수는 없다. 이는 인입농도 변화에 따른 제거율의 변화가 $61 \sim 65 \%$ 로 $4 \%$ 가 변동되는 것과 비교할 경우 상당 히 낮은 영향인 것을 알 수 있다. 이는 $\mathrm{DO}$ 제거율이 인입농 도의 변화보다 진공도는 영향을 덜 받는 것을 알 수 있다.

\subsubsection{Sweep gas $\left(\mathrm{LN}_{2}\right)$ 유량의 영향}

Sweep gas의 유량변화에 따른 제거율의 상관관계를 Table 6 및 Fig. 15에 나타내었다. 국산 MDG막의 경우 Sweep gas 인 질소의 공급량이 없을 경우 정상상태인 $0.2 \mathrm{Nm}^{3} / \mathrm{h}$ 와 비교 하여 제거율은 $7 \%$ 정도 감소하였다. 질소 공급량은 2 배 더 증가하여 $0.4 \mathrm{Nm}^{3} / \mathrm{h}$ 로 하였을 경우 제거율은 $0.2 \%$ 증가하였 다. 이는 질소 공급량을 $0.2 \mathrm{Nm}^{3} / \mathrm{h}$ 에서 $0.4 \mathrm{Nm}^{3} / \mathrm{h}$ 로 증가하 더라도 제거율에는 영향이 없는 것을 알 수 있으며, 0.2 $\mathrm{Nm}^{3} / \mathrm{h}$ 이상으로 질소 공급량을 증가할 필요가 없음을 알 수 있다.

$\mathrm{MDG}$ 공정의 운영 방법은 질소가스를 주입하는 방법과 질소가스를 주입하지 않는 방법이 있으나, 외산 막의 경우 질소가스 주입이 필수이다. 질소가스 주입의 목적은 기공 의 분포도가 넓을 경우 일부 막에서 물의 누수가 발생되고 이렇게 누수된 부분은 제거율에 영향을 주게 됨으로 효율 이 떨어지게 된다. 물의 누수를 방지하기 위해 질소가스를 주입할 경우 누수된 부분이 질소가스로 인해 제거됨으로 제거효율을 증가할 수 있게 된다. 이런 측면에서 질소가스 주입은 필요한 부분이다. 국산 $\mathrm{MDG}$ 막의 경우 앞서 막의
Table 7. Removal rate of DO according to the pressure.

\begin{tabular}{ccccc} 
& $\begin{array}{c}\text { Inlet Pressure } \\
(\mathrm{MPa})\end{array}$ & $\begin{array}{c}\text { Inlet DO } \\
(\mu \mathrm{g} / \mathrm{L})\end{array}$ & $\begin{array}{c}\text { Outlet DO } \\
(\mu \mathrm{g} / \mathrm{L})\end{array}$ & $\begin{array}{c}\text { Rejection } \\
(\%)\end{array}$ \\
\hline \multirow{2}{*}{$\begin{array}{c}\text { Domestic } \\
\text { MDG }\end{array}$} & $0.41[0.2]^{*}$ & 260 & 96 & 63 \\
\cline { 2 - 5 } membrane & $0.34[0.1]$ & 260 & 114 & 56 \\
\cline { 2 - 5 } & $0.31[0.0]$ & 260 & 106 & 55 \\
\hline
\end{tabular}

* The valve inside of the bracket indicates the pressure control valve

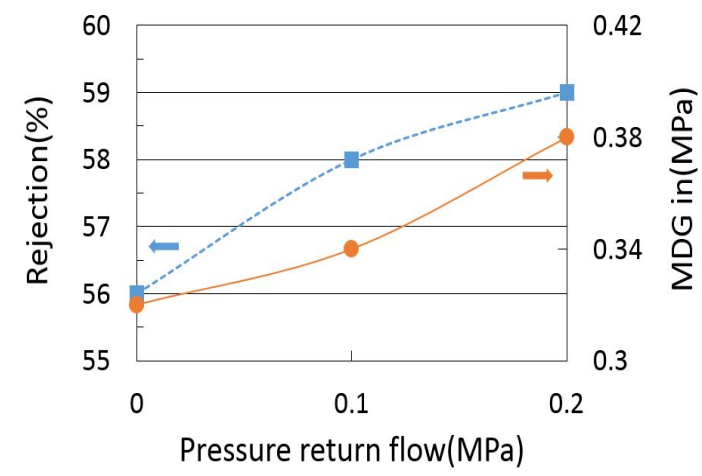

Fig. 16. Changes in DO rejection by initial inlet pressure.

확대 사진에서도 확인한 바와 분포도가 일정하여 누수가 없을 것으로 예상된다. 실제 $\mathrm{MDG}$ 공정에서 막의 누수 여 부를 확인한 결과 외산 막보다 국내 막의 누수가 적음을 알 수 있었다. 이는 외산 막보다 국산 막이 누수에 의한 막 의 제거효율 저하가 더 없을 것으로 예상된다.

질소가스의 유무에 따른 영향에 대한 $\mathrm{DO}$ 농도의 측정 결과를 보면 $30 \sim 50$ 분의 운영 결과가 안정적인 제거율을 나타내고 있다. 그러나, 막의 누수에 대한 영향은 시간이 지남에 따라 영향을 줄 수 있어서 장시간의 운영 결과로 판단이 필요한 부분이다. 즉, 질소가스를 주입하지 않고 4 시간 이상 운영 후 DO 농도를 측정하여 제거율의 변화를 확인할 필요가 있을 것으로 판단된다.

\subsection{4. 압력(Pressure)의 영향}

Liqui-cel ${ }^{\mathrm{TM}}$ 운영압력 최대값 $0.6 \mathrm{MPa}$ 과 국산 $\mathrm{MDG}$ 막 운 전압력 최대값 $0.4 \mathrm{MPa}$ 의 차이로 인한 객관적 성능평가를 위하여 압력에 따른 두 $\mathrm{MDG}$ 막의 성능변화를 평가하였다. 상관관계를 Table 7 및 Fig. 16에 나타내었다. 정상운전인 유입유량 $1.77 \mathrm{~m}^{3} / \mathrm{h}$, 회수유량 $1.15 \mathrm{~m}^{3} / \mathrm{h}$ 인 상태에서 회수압 력을 조절하였다. 회수압력이 $0.2 \mathrm{MPa}, 0.1 \mathrm{MPa}, 0.0 \mathrm{MPa}$ 로 감소함에 따라 $\mathrm{MDG}$ 유입수의 압력은 $0.38 \mathrm{MPa}, 0.34$ $\mathrm{MPa}, 0.32 \mathrm{MPa}$ 로 감소하였고, $\mathrm{DO}$ 제거율도 $59 \%, 56 \%$, $55 \%$ 로 감소하였다.

초순수 공급 압력의 영향은 앞서 언급한 진공도와 유사하게 설명이 가능하다. 정상 상태에서의 분리막 기공을 통한 $\mathrm{DO}$ 의 이동은 앞서 언급된 바와 같이 식 $1\left(J_{O_{2}}=K_{L}\left(C_{O_{2}}-C_{O_{2}}^{*}\right)\right.$ 과 
같이 표현된다. 즉, 식 1 은 $\mathrm{O}_{2}$ 이동(탈기)속도 $\left(J_{O_{2}}\right)$ 는 농도차이 $\left(C_{O_{2}}-C_{O_{2}}^{*}\right)$ 에 비례한다. 그리고, 여기서 농도차이는 물속의 $\mathrm{O}_{2}$ 농도와 진공상태의 $\mathrm{O}_{2}$ 의 차이를 나타낸다. 초순수 내의 $\mathrm{O}_{2}$ 농도는 공급 압력이 증가할수록 $\mathrm{O}_{2}$ 농도는 증가함으로 공급압력의 증가는 농도차이를 커지게 만들어 이동속도를 크 게 한다. 즉 공급압력이 증가할수록 이동속도가 빨라져서 $\mathrm{O}_{2}$ 제거율은 높아지게 된다.

Table 7 및 Fig. 16에서와 같이 공급압력이 $0.31 \mathrm{MPa}$ 에서 $0.41 \mathrm{MPa}$ 로 증가하면 제거율은 $55 \%$ 에서 $63 \%$ 로 $8 \%$ 가 증가 함으로 위에서 설명한 식 1 과 같은 실험결과이다. 그러나 진공압력에 따른 제거율 변화폭은 $1.6 \%$ 이며, 공급압력에 따 른 제거율 변화폭은 $8 \%$ 이다. 진공압력에 따른 제거율 변화 폭보다 공급압력에 따른 제거율 변화폭이 더욱 크며, 공급 압력에 따른 제거율의 영향이 큰 것을 알 수 있다.

\section{4. 결론}

1) 국내 MDG 중공사막을 개발하여 중공사막과 모듈에 대한 평가를 수행하였으며, 평가결과 중공사막 평가결과 국내 $\mathrm{MDG}$ 중공사막의 $\mathrm{DO}$ 농도가 낮은 수준이었다. 이는 liqui-Cel ${ }^{\mathrm{TM}}$ 과 국내 $\mathrm{MDG}$ 중공사막의 Porosity (\%)가 $20 \%$ 와 $60 \%$ 로 차이가 있으며, 막 기공의 균일도도 국내 $\mathrm{MDG}$ 막이 Table 2 및 Fig. 2의 막 사진에서 볼 수 있듯이 균일하여 제거효율이 높은 것으로 판단된다.

2) $\mathrm{MDG}$ 모듈에 대한 $\mathrm{DO}$ 제거율 평가 결과는 초순수 공정 의 정상적인 $\mathrm{DO}$ 농도 범위인 $10 \mu \mathrm{g} / \mathrm{L}$ 이하일 경우 0 $\mu \mathrm{g} / \mathrm{L}$ 수준으로 외산 $\mathrm{MDG}$ 막과 비교하여 제거율의 차이 가 없으나, 국내 막의 경우 DO $150 \sim 400 \mu \mathrm{g} / \mathrm{L}$ 농도에 서는 $\mathrm{DO}$ 제거율이 $61 \sim 65 \%$ 수준으로 낮아진다. 중공 사막의 평가와는 상반되는 결과를 보인다. 모듈은 가장 중요한 점이 패킹효율이며, 이는 국내 막의 패킹효율은 $\mathrm{Liqui}^{-C e l}{ }^{\mathrm{TM}}$ 막과 비교하여 $80 \sim 90 \%$ 로 낮은 수준으로 제거효율이 낮은 것으로 예상된다. 또한, 국내 $\mathrm{MDG}$ 막 의 기공 크기(Pore size)는 $0.2 \mu \mathrm{m}$ 로 기존 Liqui-Cel ${ }^{\mathrm{TM}}$ 제품의 $0.03 \mu \mathrm{m}$ 과 비교하여 커서 최소침투압력의 차이 에 의해 $\mathrm{DO}$ 제거효율이 저하된 것으로 판단된다. ${ }^{23,24)}$ 그러나 $\mathrm{MDG}$ 운전압력 $0.41 \mathrm{MPa}$ 에서 두 제품 모두 누 수가 발생하였다.

3) 진공도가 $0 \sim 0.085 \mathrm{MPa}$ 증가할수록 $\mathrm{DO}$ 제거율 $61.5 \sim$ $63.1 \%$ 로 소폭 증가하였으며, 이는 진공도가 증가할수록 액체-기체측의 압력차가 증가하고 이로 인해 확산 속도 가 증가함으로 제거율이 증가하였다. 그리고, 공급압력이 $0.32 \sim 0.41 \mathrm{MPa}$ 로 증가할수록 제거율은 $55 \sim 63 \%$ 로 증 가하였으며, 이는 액체의 압력증가로 인해 액체-기체측 의 압력차가 증가하고 이로 인해 확산 속도가 증가함으
로 제거율이 증가하였다. 마지막으로 질소 유량이 $0 \sim 0.4$ $\mathrm{Nm}^{3} / \mathrm{h}$ 증가할수록 제거율도 $56 \sim 63.3 \%$ 증가하였다. 질 소 공급량의 증가는 앞서 언급한 바와 같이 액체-기체측 의 압력차가 증가하고 이로 인해 확산 속도가 증가함으 로 제거율이 증가하였다.

4) 상용화 막과 비교하여 국산 $\mathrm{MDG}$ 막 적용을 위해 해결 해야 하는 과제는 인입 DO 농도가 $150 \sim 400 \mu \mathrm{g} / \mathrm{L}$ 로 증 가할 때 $61 \sim 63 \%$ 에 그치는 DO 제거효율을 증대시키는 것이며, 이는 막의 기공 크기를 감소시켜 최소침투압력 (breakthrough pressure)을 높임으로 누수를 적게하여 효 율을 높일 필요가 있으며, 막의 두께를 감소시켜 저항을 최소화하여 물질전달계수 및 $\mathrm{DO}$ 의 이동속도를 높여 제 거율을 높일 수 있다. 그러나, 막의 두께를 감소시키면 막의 물리적인 강도가 약해지고 막을 엮을 때 막이 부 서져서 누수가 발생할 수 있음으로 막의 두께를 최소화 하면서 막이 누수되지 않도록 물리적 강도를 갖는 개선 방안의 검토가 필요하다. 그럼으로 향후 국산 $\mathrm{MDG}$ 막 의 개선 방향은 막의 기공 크기를 줄이고, 막의 두께를 줄이는 방법으로 개선이 필요하다.

\section{Acknowledgement}

본 연구는 K-water연구원 과제인 "맞춤형 고순도 공업용 수(ASTM D5127 E-1.3) 사업 추진을 위한 실증화 운영 기 술 개발"의 지원으로 수행되었습니다. 이에 감사드립니다.

\section{References}

1. K. H. Lee, Y. J. Lee, J. L. Lim, Development of customized ultrapure water manufacturing technology for industrial use, J. Korea Water Resour. Assoc. (water and future), 47(5), 13-16(2014).

2. Korea Agency for Infrastructure technology Advancement Home Page, B. S. Choi, https://www.kaia.re.kr/portal/cargos/ attachFileDown.do?foSeqno=2700\&seqno=6727, May(2013).

3. Global Water Market 2018, Media Analytics Ltd, United Kingdom, pp. 34-35(2018).

4. A. Gabelman, S. T. Hwang, Hollow fiber membrane contactors, J. Mem. Sci., 159(1), 61-106(1999).

5. R. B. Schaffer, F. J. Ludzack, M. B. Ettinger, Sewage treatment by oxygenation through permeable plastic films, J. Mem. Sci., 32(9), 939-941(1960).

6. Z. Qi, E. L. Cussler, Microporous hollow fibers for gas absorption : I. Mass transfer in the liquid, J. Mem. Sci., 23(3), 321-332(1985).

7. R. Basu, K. K. Sirkar, Nondispersive membrane solvent back extraction of phenol, AIChE J., 36(3), 450-460(1990).

8. Y. Lv, X. Yu, S. Tu, J. Yan, E. Dahlquist, Experimental studies on simultaneous removal of $\mathrm{CO}_{2}$ and $\mathrm{SO}_{2}$ in a polypropylene hollow fiber membrane contactor, Appl. 
Energy, 97, 283-288(2012).

9. M. S. L. Tai, I. Chua, K. Li, W. J. Ng, W. K. Teo, Removal of dissolved oxygen in ultrapure water production using microporous membrane modules, J. Mem. Sci., 87(1), 99-105(1994).

10. R. J. Durham, M. H. Nguyen, Hydrophobic membrane evaluation and cleaning for osmotic distillation of tomato puree, J. Mem. Sci., 87(1-2), 181-189(1994).

11. P. Keshavarz, J. Fathikalajahi, S. Ayatollahi, Analysis of $\mathrm{CO}_{2}$ separation and simulation of a partially wetted hollow fiber membrane contactor, J. Hazard. Mater., 152(3), 1237-1247(2008).

12. K. Li, J. Kong, X. Tan, Design of hollow fibre membrane modules for soluble gas removal, Chem. Eng. Sci., 55(23), 5579-5588(2000).

13. R. Wang, H. Y. Zhang, P. H. M. Feron, D. T. Liang, Influence of membrane wetting on $\mathrm{CO}_{2}$ capture in microporous hollow fiber membrane contactors, Sep. Purif. Technol., 46(1-2), 33-40(2005).

14. C. Isetti, E. Nannei, A. Magrini, On the application of a membrane air-liquid contactor for air dehumidification, Energ Buildings., 25(3), 185-193(1997).

15. S. Khaisri, D. deMontigny, P. Tontiwachwuthikul, R. Jiraratananon, Comparing membrane resistance and absorption performance of three different membranes in a gas absorption membrane contactor, Sep. Purif. Technol., 65(3), 290-297(2009).
16. S. Koonaphapdeelert, K. Li, Preparation and characterization of hydrophobic ceramic hollow fibre membrane, J. Mem. Sci., 291(1 2), 70-76(2007).

17. Y. S. Kim, S. M. Yang, Absorption of carbon dioxide through hollow fiber membranes using various aqueous absorbents, Sep. Purif. Technol., 21(1-2), 101-109(2000).

18. 3M Liqui-Cel Home Page, http://www.liquicel.com/productinformal-tion/micromodule.cfm, (2016).

19. P. H. M. Feron, A. E. Jansen, Capture of carbon dioxide using membrane gas absorption and reuse in the horticultural industry, Energy Convers. Mgm., 36(6-9), 411-414(1995).

20. Y. An, D. Kim, H. Jo, Y. Seo, Y. Park, H. Lee, The permeation behaviors of $\mathrm{H}_{2} \mathrm{~S} / \mathrm{CH}_{4}$ using polyimide hollow fiber membranes, Membr. J., 19(4), 261-267 (2009).

21. H. J. Lee, J. H. Park, Hollow fiber membrane contactors, News \& Information for Chemical Engineers, 35(6), 602-609(2017)

22. V. Y. Dindore, D. W. F. Brilman, F. H. Geuzebroek, G. F. Versteeg, Membrane-solvent selection for $\mathrm{CO}_{2}$ removal using membrane gas-liquid contactors, Sep. Purif. Technol., 40(2), 133-145(2004).

23. M. Simioni, S. E. Kentish, G. W. Stevens, Membrane stripping: Desorption of carbon dioxide from alkali solvents, J. Memb. Sci., 378(1-2), 18-27(2011).

24. X. He, M. B. Hagg, Hollow fiber carbon membranes: Investigations for $\mathrm{CO}_{2}$ capture, J. Memb. Sci., 378(1-2), $1-9(2011)$. 